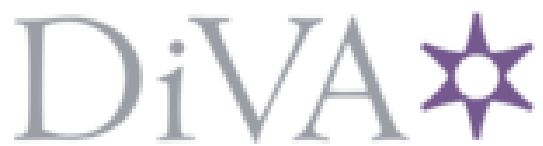

http://www.diva-portal.org

This is the published version of a paper published in Interactive Learning Environments.

Citation for the original published paper (version of record):

Sahlin, J S., Tsertsidis, A., Islam, S. (2017)

Usages and impacts of the integration of information and communication technologies

(ICTs) in elementary classrooms: case study of Swedish municipality schools

Interactive Learning Environments, 25(5): 561-579

https://doi.org/10.1080/10494820.2016.1170045

Access to the published version may require subscription.

N.B. When citing this work, cite the original published paper.

Permanent link to this version:

http://urn.kb.se/resolve?urn=urn:nbn:se:oru:diva-53965 


\title{
Interactive Learning Environments
}

\section{Usages and impacts of the integration of information and communication technologies (ICTs) in elementary classrooms: case study of Swedish municipality schools}

\author{
Johannes S. Sahlin, Antony Tsertsidis \& M. Sirajul Islam
}

To cite this article: Johannes S. Sahlin, Antony Tsertsidis \& M. Sirajul Islam (2017) Usages and impacts of the integration of information and communication technologies (ICTs) in elementary classrooms: case study of Swedish municipality schools, Interactive Learning Environments, 25:5, 561-579, DOI: $10.1080 / 10494820.2016 .1170045$

To link to this article: https://doi.org/10.1080/10494820.2016.1170045

Published online: 19 Apr 2016.

Submit your article to this journal ¿

Џ Article views: 973

View Crossmark data ¿ 


\title{
Usages and impacts of the integration of information and communication technologies (ICTs) in elementary classrooms: case study of Swedish municipality schools
}

\author{
Johannes S. Sahlin, Antony Tsertsidis and M. Sirajul Islam \\ Informatics Department, Örebro University, Örebro, Sweden
}

\begin{abstract}
During recent years, many schools have started to implement information and communication technologies (ICTs)-based learning devices (such as laptops, tablets, mobile phones, and active boards) in the classroom settings in order to increase learning outcomes. The aim of this study is to find which activities and outcomes are evident in the usages of computing devices and how those devices aid elementary-level students in their learning activities. The study includes five overt participant observations at some schools in a Swedish municipality including unstructured interviews and explains the findings through activity theory and the Alberta Education Framework for Student Learning. The major activities found were dealing with the (1) educational application assignments, (2) storytelling, (3) report writing and (4) practical interaction assignments. We concluded that ICTs aid students in becoming more concentrated, focus driven, engaged and amused, thus learning becomes more interesting.
\end{abstract}

\section{ARTICLE HISTORY}

Received 5 October 2015

Accepted 21 March 2016

\section{KEYWORDS}

One to one computing; computing in classrooms; human-computer interaction $(\mathrm{HCl})$; educational outcomes; twenty-first-century skills; learning activities; activity theory; Alberta Education Framework for Student Learning (AEFSL); elementary schools

\section{Introduction}

With the rise of new information and communication technologies (ICTs), devices like laptops, tablets and smartphones are commonly available in classrooms as a necessity to do the work at hand (Ragan, Jennings, Massey, \& Doolittle, 2014). Integration of computing devices in classroom environment is a contemporary phenomenon. One of the terminologies in this trend is popularly known as one-to-one computing (or 1:1). The 1:1 computing is viewed as a personal learning device that allows individual student immediate access to a wide range of information, web-based resources and learning communities anytime anywhere (Bebell \& Kay, 2010; Bebell \& O'Dwyer, 2010). With the use of activity theory (AT) (Engeström, 1987) and the Alberta Education Framework for Student Learning (AEFSL) (Alberta, 2011) (Figure 1), the 1:1 computing phenomenon has led us to investigate how early schools students interact through ICTs and, how ICTs are used in order to increase their competencies. Studies in general have shown that children seem to concentrate more while engaging in computer-based learning rather than the traditional one (Clarfield \& Stoner, 2005; MacArthur, Haynes, \& Malouf, 1986; Mautone, DuPaul, \& Jitendra, 2005; Ota \& DuPaul, 2002). Students who use laptops or tablets in classrooms are more interested in learning and display a greater motivation to perform better (Trimmel \& Bachmann, 2004). An empirical study about integration of 1:1 computing resources at some schools in Swedish municipalities (Lindström, 2015) shows that children perform better in schools using tablets, which is also aligned with the previous statement of Trimmel and Bachmann (2004). However, the Alliansen, an alliance of some moderate Swedish political parties, argues that 

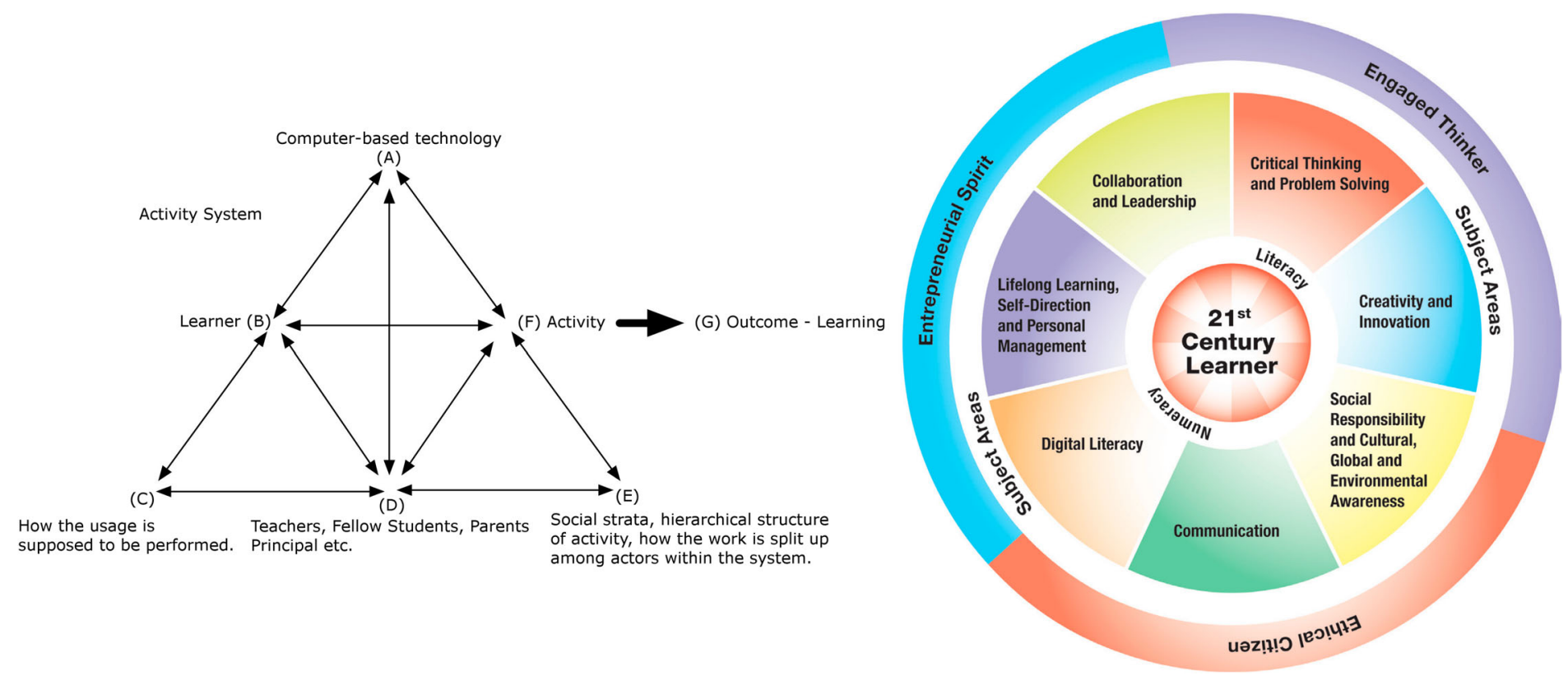

Figure 1. AT framework and the AEFSL. 
ICTs are available in classrooms but they are not used to their fullest extent (Pärsson, 2015). Driver (2002) finds that use of laptops together with web-based activities enhances students' satisfaction especially when working with group projects. Toyama (2011) in this regard cautions that ICTs are no placement for good teachers and a stronger administration and ICTs cannot replace these; but can augment good schools in striving for successful learning.

This study apparently carries practical as well as theoretical significances since the use of ICTs at an individual level in a group learning environment is quite new in the educational context at the elementary level. And this aspect of research has been emerged with debates in the contexts of usability of computers in classrooms and individual competencies (Livingstone, 2012; Van Son, 2011). There are also research interests in how students interact through ICTs and how internalization of learning takes place in the process of competence building (Nonaka \& Toyama, 2003). The difference between learning and its contributing roles toward increasing competencies is that learning is the operationalization of teaching and competencies is the internalization of learning in order to perform specific tasks. In this study, we therefore focus on investigating the roles of computing devices among school children in a classroom environment by way of operationalizing the following two research objectives: (1) How do students interact through ICTs during their classroom learning? and (2) How ICTs contribute toward students' competencies building processes?

The following texts feature a section on a brief background of computer integration in schools. Section 3 describes how participant selection took place, data were collected and analyzed. This section also explains the theoretical frameworks used. Section 4 presents the study findings followed by a discussion. Finally Section 5 highlights the research contributions, acknowledges the study limitations and suggestions for further research.

\section{A brief background of integration of computing devices in schools}

Goals relating to computer integration in schools generally relate to two perspectives - academic goals and program goals. One common integration focus is the combination of an interest in technology design and in the perspective provided by constructivist learning theory (Ackermann, 1996; Brown, Collins, \& Duguid, 1989; Papert, 1986). Constructivism in learning has been associated with various goals ranging from technically improved teaching and learning to social and even political ambitions. Such ambitions include (Grasso \& Fallshaw, 1993):

- Enhancing the learning environment by providing another medium with which to construct learning and thus achieve greater understanding.

- Enabling every learner to become a confident and competent computer user.

- Empowering learners to take an active, creative and responsible role in a technologically changing society.

The list above indicates that the constructivist learning perspective is strongly represented in 1:1 program goals. Beyond theory, the practical motivation of new requirements for the workforce in the twenty-first century is often mentioned, indeed as an argument in support of constructivist theory as this is seen as epitomizing the requirements on people in the knowledge society, being generally creative, communicative and "constructive." Other arguments, such as a technology driver due to generally increased computer use in society and an interest from industry itself may certainly be important, but in the argumentation for 1:1 programs the first two arguments are the most prominent.

While the literature studies are important, it should be noted that it is difficult to compare technology uses over long periods of time as technology has changed so much over the past decades. Early technical efforts along the line of Seymour Papert's constructionist learning thinking include the computer programming language Logo, developed for children in 1967. In order to strengthen the ability to learn knowledge, "Logo Turtle," a small robot operated by Logo, helped children to 
explore the computer in a similar way as they did in the real world while solving problems. Influenced by Logo, Alan C. Kay developed a laptop computer called Dynabook for children of all ages (Kay, 1972) based on the sketches of the KiddiComp in 1970.

Both Papert and Kay have had a profound influence on the design and goals of the one laptop per child (OLPC) programs later to come, as both of them were closely associated with educational constructivism (Zuckerman, 2007). In 1990, the Methodist Ladies College (MLC) in Melbourne, Australia, became the first school in the world to introduce a laptop program for students from 5th to 12th grade. Soon this practice became a popular focus for experiments in other schools in Australia and other parts of the world, especially in the USA. In 1992, Suffield Academy became the first high school in the USA with a 1:1 program. Theoretical ideas on "constructivist learning" and their practical implementation by means of using computers created widespread interest not only among researchers but also in industry. During 1996-1997, Microsoft convinced 52 schools in the USA to launch laptop program under a promotional campaign called "Learning with Laptops." In 2001, with the introduction of iBook laptop, Apple announced selling 23,000 second-generation iBooks for the Henrico County Public Schools' (HCPS) one-to-one laptop program. In 2002, Maine's governor Angus King convinced the Maine legislature to distribute 32,000 iBooks for all Maine seventh and eighth graders. The Maine experiences have been relatively thoroughly evaluated and served as inspiration for other programs. According to Bonifaz and Zucker (2004), "Maine has been a pioneer in the ubiquitous computing movement, providing computers and wireless Internet access to all students in grades 7 and $8^{\prime \prime}$ (p. 3). However, 1:1 computing has generally not taken off quickly in schools worldwide; as there are high costs associated and as positive effects on learning have not automatically ensued but are subject to difficult implementation issues.

Perhaps the most intriguing name among the several laptop programs in the contemporary world is the "OLPC" which has been "widely credited with creating international market pressure for the development of low-cost laptop computers for both the education sector and the general public" (Warschauer \& Ames, 2010, p. 46). OLPC is a non-profit organization and pioneered in creating a low-cost laptop designed for rough-use conditions, the XO (in 2005), as well as software and content. Nicholas Negroponte, initiator of the OLPC, worked informally together with Papert and Marvin Minsky for about a decade at the MIT media Lab and took part in several experiments on constructionist learning (Negroponte, 2006). In 1982, under a French government-sponsored pilot project, they distributed Apple II computers to school children in a suburb of Dakar, Senegal and the trial "confirms one of Papert's central assumptions: children in remote, rural, and poor regions of the world take to computers as easily and naturally as children anywhere" (laptop.org, web). Negroponte authored an influential book entitled "Being Digital" in 1995, which made up the foundation for the vision of OLPC. His empirical work in a small remote Cambodian village, where he distributed 20 laptops with Internet connection, gave him profound insights into innovative uses of computers by the children and their families.

According to OLPC, so far 2.5 million laptops have been shipped for children and teachers in Latin America ( $80 \%$ of total), Africa and the rest of the world. Major countries with significant activities of OLPC projects include Uruguay, Peru, Argentina, Mexico, Rwanda, Gaza, Afghanistan, Haiti, Ethiopia and Mongolia. Outside of developing countries, the USA alone has around 95,000 XO users so far which had been taken-up under a promotional program called "Give One Get One" during the period 2007-2008. There has been a planned full-scale deployment in Birmingham, Alabama. The program also included Canada and later had extended to EU member states, Switzerland and Russia (laptop.org, n.d.).

While large, the number is still far away from Negroponte's initial prediction of 100-150 million laptops by 2008 to targeted developing countries (Warschauer \& Ames, 2010). However in a recent interview with Xconomy, Arboleda, who is the CEO of OLPC in Miami, asserted that OLPC "has achieved its earliest goals and has been an "outstanding success," especially insofar as it gave the organization the opportunity to demonstrate, at large scale, the effectiveness of the so-called "Constructionist" theory of education" (Roush, 2014, web). 


\subsection{Uses of computing technologies in schools and their impacts}

There are several studies on laptop programs for schools report various ways of using ICTs in the learning processes and their positive impacts on the students. These, as compiled by Islam and Grönlund (2016) in their literature study, are increased engagement and motivation, improved quality of work and achievements, foster self-directing and independent learning, improved research and writing skills, enhanced computing skills, enhanced access to online contents, improved attendance and enrolment, more time on doing homework, assistance to students with special needs and increased cognitive skills.

Rockman, Walker, and Chessler's (2000) evaluation of Microsoft's "Anytime, Anywhere Learning" Program among more than 450 students of 13 schools at 12 different sites in the USA found that "computer use is most prevalent in language arts and social studies, and least prevalent in math, both in and out of school" (p. vi). The most frequent student computing activities at school were preparing assignments, writing or taking notes, and accessing emails. Main activities at home were emailing, accessing online contents and gaming. Other activities included working on assignments in small groups, doing drills to increase skills in math, English etc., creating presentations or projects, and taking quizzes, tests or assessments. These findings are consistent with the PCHS evaluation report (2004) and Constant (2011) who found that most frequent uses included language arts $(93 \%)$, science $(91 \%)$ and social studies $(88 \%)$. Students use laptops primarily for finding information (90\%), organizing information (63\%) and taking notes (57\%). Rockman's (2004) study on the US schools states that students use a calendar program in their laptop to set up due dates and daily reminders that help to increase productivity in learning. Cristia, Ibarrarán, Cueto, Santiago, and Severín (2012) measured three distinct dimensions of cognitive skills, abstract reasoning, verbal fluency and processing speed, at 319 public schools in small, poor communities in rural Peru where a large-scale OLPC project was implemented. According to them, "results indicate limited effects on academic achievement but positive impacts on cognitive skills and competences related to computer use. Cognitive abilities may arise through using the programs included in the laptops, given that they are aimed at improving thinking processes" (p. 20).

An evaluation report (Great Maine Schools Project, 2004) based on a survey conducted at Piscataquis Community High School (PCHS) Study in the USA reported that students use more time with laptops in school than at home. It further found that $81 \%$ of the surveyed students spent at least 5 hours per week using computers at school while only $46 \%$ spent the same amount of time at home. However, this seems to be changing as computer use today increasingly permeates the homes. Zucker and McGhee (2005) survey at the secondary level in HCPS, Virginia found that students used laptop in their mathematic classes for spreadsheets design, drawing programs in order to create geometric figures, and a variety of Web sites that allow teachers to create tests and review activities. Gulek and Demirtas (2005) investigated 259 students at Harvest Park Middle School, in California. The study found that students with laptops achieved better than non-laptop students in all measures after one year of implementation, including writing, mathematics and language scores, as well as overall GPAs. Also, a nine-month evaluation across six New Hampshire middle schools study (Bebell, 2005) revealed that student achievement and ability to retain content material had been improved for using laptop in their schooling. Regarding research skills, the Lowther, Strahl, Inan, and Bates's (2007) evaluation study of the Michigan Freedom to Learn program report that "nearly all students and parents reported that using laptop computers increased their research skills, made schoolwork easier and made them learn more and do better on tests" (p. 4).

There are evidences that ICTs-integrated programs strengthen the student-teachers interactions. Ardito (2011) investigated the influence of OLPC XO Laptops within five fifth-grade classrooms and demonstrated that

during the XO Laptop sessions, the number of student-student helping interactions was over five times more frequent than student-teacher helping interactions. During non-XO Laptop sessions observed, the frequency of 
student-teacher helping interactions was consistent with the XO Laptop session levels, but there were only about a quarter as many student-student helping interactions. (Ardito, 2011,n.p)

One-to-one laptop program also increase the use of technology across the curriculum, most evident in math, science and social studies classrooms (Bebell, 2005; Keengwe, Schnellert, \& Mills, 2012; Oliver \& Corn, 2008). There is an indication of a positive relationship between laptop initiatives and the fulfillment of curriculum requirements. Ingram, Willcutt, and Jordan (2008) found that $84 \%$ of the surveyed teachers agree that they are better able to meet their curriculum goals when students use computers. Differentiating the curriculum and their instruction allows students to work at different levels of depth (Fairman, 2004).

\section{Methods}

\subsection{Research approach}

This study is based on a qualitative research approach (Oates, 2006) that uses observations and interviews at three municipality schools as a collective case study. It has used AT (Engeström, 1987) as well as AEFSL (Alberta, 2011) as lenses for data analysis. We find that the qualitative case study approach is suitable to obtain a rich insight as Oates (2006) also states that case studies look the real-life context of the phenomenon and dive deep into its complexity (contrary to more shallow strategies). Unstructured interviews were also conducted in between or during our observations as a means to receive additional information that could not be spotted by just observing.

In this study, we have focused on elementary schools in the vicinity of the Örebro municipality which is the sixth biggest in Sweden with a population of approximately 140 thousands. We chose the Örebro municipality for demographic convenience, such as accessibility and proximity. We had contacted all 59 schools $^{1}$ through emails. As we had four responses during the initial communication, we started calling and visiting these schools in order to get allowance to conduct our empirical investigation. Among them, six schools responded that they did not have any ICT available in their classrooms; five schools had refused us and twelve schools we got in touch with but never got approval to visit them. We eventually got an appointment from a school (Karl Johan skolan) which was outside of our age limit (ages seven to ten years), this particular age limit was selected because of the lower level of influence by the ICTs. We, however, had conducted seven test visits to different classrooms (with ages 13-15 years) of this school in order to evaluate our research strategy. Finally, we ended up with three municipality schools (Table 1) who had extended their fullest cooperation for carrying out our fieldwork.

The observations were conducted using a systematic design strategy (Oates, 2006) performed in a standard ethical manner by upholding confidentiality, privacy and anonymity of the students. We did not ask for students' consent but were given consent by the school authorities. As observers, we introduced ourselves in the classrooms and mentioned that we were there just for observations and we would not intervene the learning sessions. Additionally, we mentioned that we were there to look at their interaction with their computing devices, such as tablets available in the classrooms. We mostly stood in one place (initially in the back of the classroom, behind the students) trying to

Table 1. Visited schools and brief descriptions.

\begin{tabular}{|c|c|}
\hline $\begin{array}{l}\text { Schools and classrooms } \\
\text { visited }\end{array}$ & Brief description of the schools \\
\hline $\begin{array}{l}\text { Hannaskolan }\left(P^{2}-9\right) \\
\text { Second grade }\end{array}$ & $\begin{array}{l}\text { Hannaskolan has a Christian value foundation, founded in } 1987 \text { and was one of the first non- } \\
\text { government schools in the municipality of Örebro. It has about } 330 \text { students and } 65 \text { personnel. It is } \\
\text { located in the western part of Örebro (Väster). }\end{array}$ \\
\hline $\begin{array}{l}\text { Eklundaskolan (P-3) } \\
\text { first and second grades }\end{array}$ & $\begin{array}{l}\text { Eklundaskolan focuses on values such as security, joy and curiosity. It has about } 180 \text { pupils and } 25 \\
\text { personnel. It is located in the southern part of Örebro (Sörby). }\end{array}$ \\
\hline $\begin{array}{l}\text { Bruketsskola (P-6) } \\
\quad \text { first and fourth grades }\end{array}$ & $\begin{array}{l}\text { Bruketsskola, founded in the early 1960s, focuses on a variety of cultural and physical activities } \\
\text { among pupils (with } 20 \text { different native languages). It has about } 150 \text { pupils and } 30 \text { personnel. }\end{array}$ \\
\hline
\end{tabular}


have a clear view of all students; when needed, we moved to another spot so we could capture their activities as far as possible.

At every school visited, we (two of the three authors of this paper) were in the classrooms throughout the lessons (90 minutes each). During their lessons, we noted everything according to our observation checklist (Please see Tables 6-10). Each observer conducted the observations independently and afterwards all results were discussed and combined. As Oates (2006) recommends, one should rely on field notes once an observer finds something relevant as one cannot possibly remember everything during the observation and therefore need field notes. Between the lectures, we also took time to interview teachers. During these unstructured interviews, we took extra notes in order to increase data validity (Oates, 2006).

\subsection{Conceptual framework used}

AT used in this study helps to conceptualize the learning activity (Figure 1) in which the AEFSL connects through the outcome element of AT (Figure 1). Both these frameworks were selected due to their credibility, ease of understanding and suitability in the similar kind of studies. AT is a commonly used framework in other studies such as Wilson's (2014), Karanasios (2014). Hashim and Jones (2007) state that "from the work of Scanlon and Issroff (2005) there is copious evidence that Activity Theory is appropriate for education research." Please see Table 2 which defines the elements of AT relevant to our study.

The AEFSL and its areas of "competencies" is the result of a review of educational literature online consultations and face-to-face engagements with educators, parent groups, teachers, school administrators, researchers, employers, non-governmental organizations and students by the Alberta Education Ministry in Canada. In short it is a model composed of competencies which can be derived from successful learning. Table 3 introduces the chosen components of AEFSL relevant to our study.

Our focus in the AEFSL is mainly the secondary inner circle, showing the subject/discipline areas. In the case of integration of computers in classes, we decided not to observe areas such as lifelong learning and environmental responsibility, as a more extensive timeframe was needed to make a

Table 2. Introducing the elements of AT.

\begin{tabular}{|c|c|c|}
\hline Element & $\begin{array}{l}\text { As shown in } \\
\text { Figure } 1\end{array}$ & Description \\
\hline Tools & A & The ICT devices, such as computers, laptops, tablets and mobile phones. \\
\hline Community & D & $\begin{array}{l}\text { The social group or environment where the activity takes place, in this case schools, and, } \\
\text { going a step further, we can include everyone who is part of the environment where the } \\
\text { activity takes place. }\end{array}$ \\
\hline Subject & B & Our subjects in this study are first to fourth-grade students (7-10 years old). \\
\hline $\begin{array}{l}\text { Division of } \\
\text { labor }\end{array}$ & $\mathrm{E}$ & How work gets split up between actors, how it is performed. \\
\hline Rules & $\mathrm{C}$ & $\begin{array}{l}\text { Norms and practices that influence activities. This revolves around the devices used, rules } \\
\text { regarding the usage of devices, etc. }\end{array}$ \\
\hline Object & $\mathrm{F}$ & The activities that take place in the environment. \\
\hline Outcome & G & A consequence of all elements in actions. \\
\hline
\end{tabular}

Table 3. Introducing the elements of AEFSL.

\begin{tabular}{ll}
\hline Element & Description \\
\hline Student & Main participants of the study in a classroom setting. \\
$\begin{array}{l}\text { Literacy and } \\
\text { numeracy }\end{array}$ & Being literate and numerate means exceeding the elemental skills of reading, writing and solving simple \\
Competencies & arithmetic issues to acquiring, creating, connecting and understanding information (Alberta, 2011). \\
& An interconnected set of attitudes, skills and knowledge, which are evolved over time, necessary in a \\
particular context for successful learning and living (Alberta, 2011).
\end{tabular}


reliable judgment on lifelong learning aspects. Environmental responsibilities were not selected, as they were not applicable in the classroom context. Therefore, the following issues were selected: (1) Critical thinking, Problem-solving and Decision-making, (2) Creativity and Innovation, (3) Collaboration and Leadership, (4) Digital and Technological Fluency and (5) Communication.

Table 4 explains and illustrates how we have used this calculation for determining the strength of each competency table. Objectives are listed vertically and numbered. The objectives in this case are derived from each competency category of the AEFSL (Tables 6-10 for all categories and their respective objectives). The objective score for each objective can be found furthest to the right in their row. Horizontally for each objective, one can see the individual score of each school and their classrooms. Overall scores throughout the schools and classrooms can be read vertically. The calculation result (score) presented above is used by entering the total objective score for each competency group, where the left value in the table is the "Found objectives" and the right value is "Top objectives." A higher score means that the presence of the competency is stronger.

\section{Results and discussion}

This section presents the results of our empirical study. First, we present the six elements of AT (Table 5), which are tools, subject, rules, community, division of labor and object for each school accordingly. Finally, we present the "outcomes" derived through "object" in a combination with all the schools investigated.

Table 4. Description of how to read the score table of a competency group.

\begin{tabular}{|c|c|c|c|c|c|c|}
\hline \multirow[b]{2}{*}{ Obj. } & \multirow{2}{*}{$\begin{array}{l}\text { Competency group : } \\
\text { Critical thinking, problem- } \\
\text { solving and decision- } \\
\text { making }\end{array}$} & \multirow{2}{*}{$\begin{array}{l}\text { Eklunda } \\
\text { First } \\
\text { grade }\end{array}$} & \multirow{2}{*}{$\begin{array}{l}\text { Hanna } \\
\text { Second } \\
\text { grade }\end{array}$} & \multicolumn{2}{|c|}{ Brukets } & \multirow{2}{*}{$\begin{array}{l}\text { Total } \\
\text { objective } \\
\text { score } \\
\text { Fourth } \\
\text { grade }\end{array}$} \\
\hline & & & & $\begin{array}{l}\text { Second } \\
\text { grade }\end{array}$ & $\begin{array}{l}\text { First } \\
\text { grade }\end{array}$ & \\
\hline $\begin{array}{l}\text { 1. Students (a) review, (b) analyze and } \\
\text { (c) assess information from a variety } \\
\text { of sources and points of view. }\end{array}$ & NO & YES & $(b+c)$ & NO & $\mathrm{N} / \mathrm{F}$ & $1 / 4$ \\
\hline $\begin{array}{l}\text { 2. They use metacognition to (a) reflect } \\
\text { on their thinking and (b) recognize } \\
\text { strengths and weaknesses in their } \\
\text { reasoning and in the positions } \\
\text { presented by others. }\end{array}$ & $N / F$ & $N / F$ & $N / F$ & $N / F$ & $N / F$ & $0 / 0$ \\
\hline $\begin{array}{l}\text { 3. Students have the (a) confidence and } \\
\text { (b) capacity to solve a range of } \\
\text { problems, from simple to complex } \\
\text { and including novel related to their } \\
\text { learning. }\end{array}$ & YES & YES & YES & NO & YES & $4 / 5$ \\
\hline $\begin{array}{l}\text { 4. They (a) use multiple approaches to } \\
\text { solving a problem and (b) understand } \\
\text { that a problem can have several } \\
\text { solutions. }\end{array}$ & NO & YES & NO & NO & NO & $1 / 5$ \\
\hline $\begin{array}{l}\text { 5. They use a variety of resources in } \\
\text { arriving at a solution and use the } \\
\text { knowledge and experience gained to } \\
\text { inform their ability to solve problems } \\
\text { and make decisions. }\end{array}$ & YES & YES & YES & YES & YES & $5 / 5$ \\
\hline Classroom score & $2 / 4$ & $4 / 4$ & $2 / 4$ & $1 / 4$ & $2 / 3$ & $11 / 19$ \\
\hline
\end{tabular}


Table 5. Results presented in accordance with the components of AT.

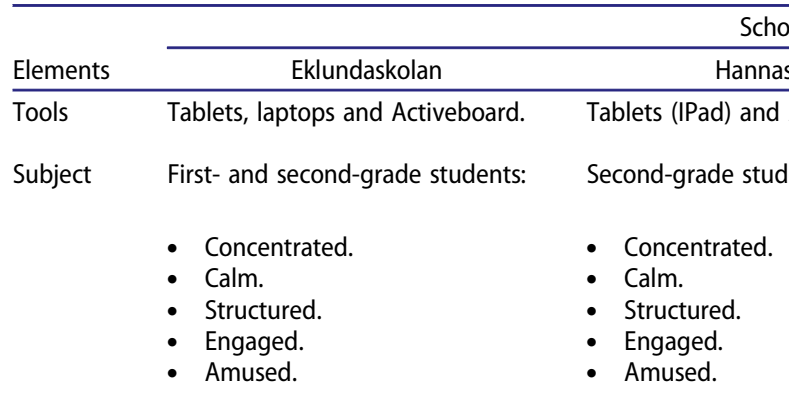

Rules

First-grade students

Tablets

Brukets skolan

First grade: Tablets only Fourth grade: Tablets and projectors.

First- and fourth-grade students:

- Concentrated.

- Calm.

- Structured.

- Engaged.

- Amused.

- Impatient - first graders.

- Not allowed to browse the Internet or videos without permission.

- Not allowed to deviate from the course applications.

- Not allowed to carry their devices around the classrooms.

- When battery status fell under $50 \%$, the devices were put into a specific pile for recharging.

- Not allowed to install or delete applications.

Second-grade students

- Not allowed to browse the Internet without permission.

- Allowed to carry devices around.

- Supervision was more relaxed compared to first-grade students.

- Not allowed to deviate from the course materials.

- Not allowed to install or delete applications.

- When battery status fell under $50 \%$, the devices were put into a specific pile for recharging.
- Not allowed to run and carry the tablets at the same time.

- When walking with the tablet, the device should be carried out using both hands.

- Usage only under supervision and only inside the classroom.

- Installation of other apps had to be approved by the teacher.

- Neither internet nor video searching was allowed. Usage was limited to educational applications.

\section{Activeboard}

- Maximum three students per device (1:3)

- Students were not allowed to choose applications/tasks by themselves.

- They were not allowed to use the computers connected to the Activeboard.
First-grade students

- No specific set of rules.

- Supervised use of tablets at all times.

- Not allowed to carry them around.

- No individual use, very restricted and limited usage.

Rules - fourth-grade students

- No specified set of rules.

- Supervision was more relaxed compared to first graders.

- They were allowed to carry them around.

- Had to deliver them back to the teacher after the end of lessons.

- Could request an app to install.

- Not allowed to install apps without permission.

- They were not allowed to remove any preinstalled apps.

- Students could not deviate from the lessons while using tablets.

- Not allowed to browse the internet without permission.
Community Teachers, fellow students, assistants ${ }^{3}$, Teachers, fellow students and parents.

Division of Tablets:

labor Teacher hands out assignments through a network (laptop). Students perform the tasks through the devices, and teacher corrects the assignments, monitors results and reissues assignments if needed. Ipads:

Teacher hands out instructions of what to do during classes, the applications used by the ipads are, presenting, calculating and correcting the student. Concerned teacher then monitors the results and reissues assignments if needed.

\section{assistants.}

First-grade students:

Teacher hand out the assignment verbally. Then students complete the given task with the teachers' aid. The tablet displays images, records and plays back the produced story (Storytelling with audio). Second-grade students:

The teacher hands out the assignment verbally along with a manuscript, and uses the projector to present the new application. The students complete the manuscript and then use their tablets to record both audio and video. The tablet is then used as
Teachers, fellow students, assistants.

First-grade students:

Teacher hands out the assignment verbally. Then students complete the given task with the teachers' aid. The tablet displays images, records and plays back the produced story (Storytelling with audio). Second-grade students:

The teacher hands out the assignment verbally along with a manuscript, and uses the projector to present the new application. The students complete the manuscript and then use their tablets to record both audio and video. The tablet is then used as 
Table 5. Continued.

\begin{tabular}{|c|c|c|c|}
\hline \multirow[b]{2}{*}{ Elements } & \multicolumn{3}{|c|}{ Schools } \\
\hline & Eklundaskolan & Hannaskolan & Brukets skolan \\
\hline & & $\begin{array}{l}\text { means to play their recorded work. } \\
\text { In addition, the tablet is used a tool } \\
\text { to share their work with the } \\
\text { teacher. The teacher then picks up } \\
\text { their work and corrects them. }\end{array}$ & $\begin{array}{l}\text { means to play their recorded work } \\
\text { In addition, the tablet is used a tool } \\
\text { to share their work with the } \\
\text { teacher. The teacher then picks up } \\
\text { their work and corrects it. }\end{array}$ \\
\hline Object & $\begin{array}{l}\text { Writing reports individually and in } \\
\text { groups, playing educational games, } \\
\text { storytelling, creating movies in } \\
\text { group assignment and activeboard } \\
\text { assignments. }\end{array}$ & $\begin{array}{l}\text { Activeboard lesson with interaction, } \\
\text { educational games through the } \\
\text { tablets. }\end{array}$ & $\begin{array}{l}\text { Storytelling, creating movies in } \\
\text { groups (first grade audio } \\
\text { storytelling, second grade video } \\
\text { and audio storytelling). }\end{array}$ \\
\hline
\end{tabular}

\subsection{Tools}

The tools identified in these three schools were tablets, laptops and active boards. In fact, there is no single category of device that is being used in most of those kinds of schools integrating computers in their learning programs. In other words schools use a variety of devices in their education activities. Therefore they are flexible to create a diverse technological environment for the students (Islam \& Andersson, 2016). Tablets were the most commonly used device; but there were two participant groups (Eklundaskolan) that used laptops in combination with tablets. Eklunda had at their disposal all three devices but we did not notice them using the active board even though the teachers informed us that they use it daily. Laptops were found to be a more convenient tool for writing with, than tablets. We found that the active board to be a great asset for collaboration training among the second graders of Hannaskolan. Tablets seemed to be the most convenient devices for students to use, as well as the most program-diversified devices and this is probably why they used them so frequently in classrooms.

\subsection{Subject}

The subjects in our study ranged from seven (first grade) to ten years old students (fourth grade). The fourth graders however behaved more maturely than the younger participant groups. All student

Table 6. Critical thinking, problem-solving and decision-making among the participant groups.

\begin{tabular}{|c|c|c|c|c|c|c|}
\hline \multirow[b]{2}{*}{ Critical thinking, problem-solving and decision-making } & \multicolumn{2}{|c|}{ Eklunda } & \multirow{2}{*}{$\begin{array}{l}\text { Hanna } \\
\text { Second }\end{array}$} & \multicolumn{2}{|c|}{ Brukets } & \multirow[b]{2}{*}{ Total } \\
\hline & First & Second & & First & Fourth & \\
\hline $\begin{array}{l}\text { 1. Students (a) review, (b) analyze and (c) assess information from a variety of } \\
\text { sources and points of view. }\end{array}$ & NO & YES & $(b+c)$ & NO & $\mathrm{N} / \mathrm{F}$ & $1 / 4$ \\
\hline 2. They use metacognition to (a) reflect on their thinking and (b) recognize & $\mathrm{N} / \mathrm{F}$ & $\mathrm{N} / \mathrm{F}$ & $\mathrm{N} / \mathrm{F}$ & $\mathrm{N} / \mathrm{F}$ & $\mathrm{N} / \mathrm{F}$ & $0 / 0$ \\
\hline
\end{tabular}
strengths and weaknesses in their reasoning and in the positions presented by others.

3. Students have the (a) confidence and (b) capacity to solve a range of problems, YES YES YES NO YES $\quad 4 / 5$ from simple to complex and including novel related to their learning.

4. They (a) use multiple approaches to solving a problem and (b) understand that NO YES NO NO NO $\quad$ N/5 a problem can have several solutions.

5. They use a variety of resources in arriving at a solution and use the knowledge YES YES YES YES YES 5/5 and experience gained to inform their ability to solve problems and make decisions. 
Table 7. Creativity and innovation among the participant groups.

\begin{tabular}{|c|c|c|c|c|c|c|}
\hline \multirow[b]{2}{*}{ Creativity and innovation } & \multicolumn{2}{|c|}{ Eklunda } & \multirow{2}{*}{$\begin{array}{l}\text { Hanna } \\
\text { Second }\end{array}$} & \multicolumn{2}{|c|}{ Brukets } & \multirow[b]{2}{*}{ Total } \\
\hline & First & Second & & First & Fourth & \\
\hline 1. Students are (a) optimistic, (b) curious and (c) open to new and diverse ideas. & YES & YES & YES & YES & YES & $5 / 5$ \\
\hline $\begin{array}{l}\text { 2. They (a) appreciate the creative works of others, (b) value aesthetic expression } \\
\text { and (c) demonstrate initiative, imagination, spontaneity and ingenuity in a range } \\
\text { of creative processes. }\end{array}$ & NO & YES & (c) & (c) & YES & $2 / 5$ \\
\hline 3. They generate original ideas. & NO & YES & YES & YES & YES & $4 / 5$ \\
\hline $\begin{array}{l}\text { 4. They (a) recognize and (b) accept mistakes as part of the creative process and } \\
\text { as an opportunity to learn? }\end{array}$ & YES & YES & YES & NO & YES & $4 / 5$ \\
\hline 5. Students demonstrate (a) flexibility and (b) adaptability in response to change. & NO & YES & $\mathrm{N} / \mathrm{F}$ & YES & YES & $3 / 4$ \\
\hline \multirow{2}{*}{$\begin{array}{l}\text { 6. They (a) embrace ambiguity and uncertainty and (b) are willing to take risks, } \\
\text { and (c) demonstrate initiative, resiliency and perseverance when faced with } \\
\text { obstacles and challenges. }\end{array}$} & NO & (c) & NO & NO & (c) & $0 / 5$ \\
\hline & $2 / 6$ & $5 / 6$ & $3 / 5$ & $3 / 6$ & $5 / 6$ & $18 / 29$ \\
\hline
\end{tabular}

groups showed signs of being able to operate the devices in an appropriate way and handle according to the rules set by the teachers. The younger the participant groups, the less technological fluency had been apparent.

The students were found to be concentrated, apparently devoting all their attention to the assigned tasks. They became concentrated because they had to complete the tasks assigned by their teachers on time. While doing so they were calm and performed the assigned tasks in a structured way. They were amused during the use of educational applications and entertained because of nature of the contents. The students were found engaged in the ICT integrated educational activities because they were apparently motivated with some kind of incentives, for example, extra break, freedom to choose applications. One observation (first grade and less level of concentration) that

Table 8. Communication among the participant groups.

\begin{tabular}{|c|c|c|c|c|c|c|}
\hline \multirow[b]{2}{*}{ Communication } & \multicolumn{2}{|c|}{ Eklunda } & \multirow{2}{*}{$\begin{array}{l}\text { Hanna } \\
\text { Second }\end{array}$} & \multicolumn{2}{|c|}{ Brukets } & \multirow[b]{2}{*}{ Total } \\
\hline & First & Second & & First & Fourth & \\
\hline $\begin{array}{l}\text { 1. Students (a) understand and (b) interpret the thoughts, ideas and } \\
\text { emotions of others and (c) express themselves clearly and effectively, in } \\
\text { appropriate ways. }\end{array}$ & YES & YES & YES & NO & YES & $4 / 5$ \\
\hline $\begin{array}{l}\text { 2. Depending on the context, they choose the appropriate medium through } \\
\text { which to communicate. }\end{array}$ & $\mathrm{N} / \mathrm{F}$ & YES & YES & NO & YES & $3 / 4$ \\
\hline $\begin{array}{l}\text { 3. They communicate formally and informally within literary, mathematical, } \\
\text { scientific, social and artistic contexts. }\end{array}$ & YES & YES & YES & NO & YES & $4 / 5$ \\
\hline $\begin{array}{l}\text { 4. They use a variety of verbal and nonverbal modes to communicate with } \\
\text { people from diverse cultural backgrounds. }\end{array}$ & $\mathrm{N} / \mathrm{F}$ & $N / F$ & $N / F$ & $N / F$ & $N / F$ & $\mathrm{~N} / \mathrm{F}$ \\
\hline \multirow{2}{*}{$\begin{array}{l}\text { 5. Students (a) demonstrate the ability to listen with purpose and (b) } \\
\text { interact respectfully with others, (c) read for information and enjoyment, (d) } \\
\text { speak and (e) write appropriately. }\end{array}$} & YES & YES & YES & $(a+b+d)$ & YES & $4 / 5$ \\
\hline & $3 / 3$ & $4 / 4$ & $4 / 4$ & $0 / 4$ & $4 / 4$ & $15 / 19$ \\
\hline
\end{tabular}


Table 9. Digital fluency among the participant groups.

\begin{tabular}{|c|c|c|c|c|c|c|}
\hline \multirow[b]{2}{*}{ Digital and technological fluency } & \multicolumn{2}{|c|}{ Eklunda } & \multirow{2}{*}{$\begin{array}{l}\text { Hanna } \\
\text { Second }\end{array}$} & \multicolumn{2}{|c|}{ Brukets } & \multirow[b]{2}{*}{ Total } \\
\hline & First & Second & & First & Fourth & \\
\hline $\begin{array}{l}\text { 1. Students competently use ICTs as tools in a variety of digital environments } \\
\text { and media. }\end{array}$ & YES & YES & YES & NO & YES & $4 / 5$ \\
\hline $\begin{array}{l}\text { 2. Students access information from a variety of sources to (a) learn } \\
\text { individually or with others, (b) to communicate, (c) to come to new } \\
\text { understandings, (d) to inform problem-solving and (e) support decision- } \\
\text { making. }\end{array}$ & YES & YES & YES & NO & $N / F$ & $3 / 4$ \\
\hline $\begin{array}{l}\text { 3. They are (a) aware of current and emerging ICTs and (b) choose with } \\
\text { confidence the appropriate technology for a defined purpose? }\end{array}$ & YES & YES & $N / F$ & NO & $N / F$ & $2 / 3$ \\
\hline $\begin{array}{l}\text { 4. Students can (a) access, (b) understand and (c) manipulate digital } \\
\text { information creatively and effectively for learning, for communication and for } \\
\text { sharing and creation. }\end{array}$ & $(a+b)$ & YES & YES & NO & YES & $3 / 5$ \\
\hline \multirow[t]{2}{*}{$\begin{array}{l}\text { 5. They use technology critically and safely, and in an ethically responsible } \\
\text { manner. }\end{array}$} & YES & YES & YES & NO & YES & $4 / 5$ \\
\hline & $4 / 5$ & $5 / 5$ & $4 / 4$ & $0 / 5$ & $3 / 3$ & $16 / 21$ \\
\hline
\end{tabular}

Table 10. Collaboration and leadership among the participant groups.

\begin{tabular}{|c|c|c|c|c|c|c|}
\hline \multirow[b]{2}{*}{ Collaboration and leadership } & \multicolumn{2}{|c|}{ Eklunda } & \multirow{2}{*}{$\begin{array}{l}\text { Hanna } \\
\text { Second }\end{array}$} & \multicolumn{2}{|c|}{ Brukets } & \multirow[b]{2}{*}{ Total } \\
\hline & First & Second & & First & Fourth & \\
\hline 1. Students demonstrate leadership in their communities. & NO & NO & NO & NO & NO & $0 / 5$ \\
\hline $\begin{array}{l}\text { 2. They seek to provide (a) guidance, (b) inspire others to action and (c) direct or } \\
\text { influence others to achieve a shared purpose or vision. }\end{array}$ & YES & YES & YES & YES & YES & $5 / 5$ \\
\hline $\begin{array}{l}\text { 3. They build respectful, caring and effective relationships to (a) manage conflict } \\
\text { and differences and to (b) seek consensus in the pursuit of common goals. }\end{array}$ & YES & YES & YES & YES & YES & $5 / 5$ \\
\hline 4. They share responsibility as team members. & YES & YES & YES & YES & YES & $5 / 5$ \\
\hline $\begin{array}{l}\text { 5. In a team situation, they work with others (a) to influence, (b) motivate and (c) } \\
\text { mentor all members. }\end{array}$ & YES & YES & $\mathrm{N} / \mathrm{F}$ & YES & YES & $4 / 4$ \\
\hline \multirow[t]{2}{*}{$\begin{array}{l}\text { 6. They show flexibility in being able to work with a diversity of people in varying } \\
\text { situations. }\end{array}$} & YES & YES & YES & $\mathrm{N} / \mathrm{F}$ & $\mathrm{N} / \mathrm{F}$ & $3 / 3$ \\
\hline & $5 / 6$ & $5 / 6$ & $4 / 5$ & $4 / 5$ & $4 / 5$ & $22 / 27$ \\
\hline
\end{tabular}

should also be mentioned is that the students also displayed impatience toward those devices. It became evident as some of the students wanted to leave the classroom and complete the tasks as soon as possible. This could have happened due to some other students who were not so eager about the assigned activities and tried to influence others in the groups.

\subsection{Rules}

In the absence of a written code of conduct, there were implicit rules about the usage of computing devices. The most frequently mentioned rule was that the students were not allowed to uninstall or install any application on any device of their own without any consent from their teachers. Without 
being instructed, they were even not allowed to use the devices. The younger the students were, the more limited their usage and interaction with the devices became.

\subsection{Community}

In all participation groups, we found teachers were the highest form of authority followed by assistants and then personnel in the classrooms. Fellow students were also the part of the community but at the lowest hierarchical level. However, we found that parents could monitor the progress of their children through their own external applications at home. However this (monitoring activity) was not present during school hours and thus the hierarchical level of the parents could not be confirmed in the classrooms.

\subsection{Division of labor}

Initially students were given a set of instructions by their teachers, in order to complete their assignments. Depending on the environment, the students would use either tablets, laptops or an active board to complete their assignments. We can note a difference in how these devices served as a medium of aiding learning activities. The applications would correct the students if they gave wrong answers and prompt them to try again. The teachers were present at all time, monitoring student performance and providing guidance when needed. Laptops were mostly used as a word processing device and left the correction part to the teachers. The active board facilitated the students to collaborate. The collaboration between the students consisted of using the active board in a manner of teamwork, dividing the tasks among themselves. For example, individual student could use the digital tools provided by the active board while the others could note down the results. Then they would ask the teacher to correct the results since the active board had no means for corrections.

\subsection{Object}

In most cases, the activities that took place while observing the participant groups were storytelling, movie making and word processing. Other activities were the use of educational games as a mean of promoting education through entertainment. According to Hsu (2011) the activities the teachers handout to the students are influenced by their own usage of ICTs. Teachers that use more complicated applications (e.g. multimedia programs) tend to include more frequent use of ICTs in their classroom activities rather than the teachers who use less complicated applications (e.g. word processing tools).

\subsection{Outcomes}

The "outcome" component of AT in this paper is explained through the AEFSL in order to determine competencies of the learners during the classroom learning environment. According to our observations, the degree of apparent competencies varied. Some competencies were harder to detect due to the ICTs-based experience factors. For example, teachers with more familiarity with ICTs know more about the potentials of ICTs than the less experienced teachers. In this case, it was the teachers who initiated students' learning activity and not the ICT per se. The teacher's guidance along with the ICT devices was the catalysts of the educational activity (Norris \& Soloway, 2010). This is also in line with Toyama (2011) who states that ICT alone cannot replace "good education." In order to find the link between the learning context and students' cognitive skills, it is important to mention that amusement in learning is apparently a core aspect which leads toward educational engagement and concentration. This in turn, as we observed in our cases, leads toward calmness and 
structuredness. Upholding these aspects will all contribute toward the competencies in some way, either directly or indirectly.

Below we present the results of each competency category in accordance with the AEFSL. Note that "NO" as shown in Tables 6-10 stands for a strong impression that the following "objectives" are not present at all and "YES" is the opposite. In addition, "NOT FOUND (N/F)" implies that we could not able to clearly observe the given elements during the observation and therefore these are not counted in the total scores. "Objectives" have been also been split into several parts indicated by a letter. A displayed letter in the results indicates that this part was present and therefore these are not counted in the total score either. The total score of each "objective" is then displayed horizontally for convenience and indicates how strongly that objective was present in each table. Additionally, we present how strongly each participant group scored vertically in each table.

\subsubsection{Critical thinking, problem-solving and decision-making}

In our study, the students had showed signs of critical thinking, problem-solving and decision-making by scoring a total score of $11 / 19$ (58\%) (Table 6). When the students were asked to answer certain questions, they were able to utilize the devices to search the web for answers. Since the web can provide with multiple sources and choices of information; such an openness of availability of information aid students to become critical in their thinking and decision-making processes. Also, students had shown their capabilities and confidence to solve the given tasks by addressing the problem-solving issues in an effective way.

According to our observations, the first objective under this category scored $1 / 4$; because the students in most participant groups were not allowed to search websites. The second objective was not discovered in any of the participant groups and thus received 0/0 score. The students had the confidence and capacity to solve the problems presented to them, so objective three received a score of $4 / 5$. Objective four was found once because the students did not have at their disposal many options to confirm this objective, with an exception of Eklunda second graders, who had more than one device at their disposal and were able to choose which ICT device to use to complete their assignment. As for objective five, we found that the community to be a resource for the students in their learning activities. They had then used their community (fellow students, teachers) to arrive at a solution regarding their tasks.

\subsubsection{Creativity and innovation}

Regarding student's creativity and innovation, they scored a total of 18/29 (62\%) (Table 7). The tasks assigned by the teachers were not rigid in general and the students were to decide what to choose and prioritize which on the other hand had apparently paved the path for creativity and innovation. In the first objective, all participant groups had showed the signs of optimism, curiosity and openmindedness to diverse ideas and therefore it scored $5 / 5$. The second objective scored $2 / 5$ as in most "participant groups" (point " $c$ ") was present except for Eklunda first graders. The students were able to generate original ideas (taking their environment and capabilities into consideration) and thus the third objective scored 4/5. The fourth objective for Creativity and Innovation scored 4/5. In the fifth objective, we found that some participant groups were presented with situations they had not worked with before (displaying flexibility and adaptability toward change); thus this objective scored 3/4. The sixth objective scored $0 / 5$ points but two participant groups displayed initiative, resiliency and perseverance when faced with obstacles and challenges (see point $\mathrm{c}$ ).

\subsubsection{Communication}

Communication scored a total of $15 / 19$ (79\%) (Table 8 ). The communications competencies achieved not just through the school but also through the processes of informal social interactions and development. In our case, we were presented in some situations where the students had to form groups to solve their assigned tasks. To do so, they had to show signs of understanding and efforts on interpreting the thoughts and ideas of their classmates as well as their teacher; thus the score of $4 / 5$ for the 
first objective. The second objective scored 3/4, as the students were able to choose from different interaction approaches (devices, programs, etc.) while working on their tasks. In regard to the third objective, we had looked at whether communication behavior (verbal communication) toward teachers and students was formal or informal. Where formal is an appropriate and respectable way of communicating with authority and fellow students and informal as the opposite - inappropriate and disrespectful. Overall, the students communicated in a very formal way with teachers and fellow students; hence the score of $4 / 5$. The fourth objective was not applicable since we could not measure whether the students would use a variety of verbal and nonverbal modes to communicate with people from diverse cultural backgrounds through their tablets. The situations we were given could not justify any appropriate conclusions nor were there any statements or obvious differences between their cultural backgrounds, except for ethnic traits among a few students. Moving along to the last objective of Communication, we found that $4 / 5$ participant groups demonstrated the ability to listen with purpose and interact respectfully with others as well as read for information and enjoyment and speak and write appropriately.

\subsubsection{Digital fluency}

Students seemed fluent in operating digital devices. The instructions of the teachers, class assignments and peer influence serve as catalyst for developing digital fluency. When asked whether they had owned computing devices at home, the majority replied positively and we could notice that when the students were given such devices, they knew what had to be done and how the devices should be operated without any instructions beforehand. Therefore it scores a total of 16/ 21 (76.2\%) (Table 9). The first objective in Table 9 scored 4/5 and was fulfilled by almost each participant group except the first graders of Brukets which mentioned that they all had tablets of their own, but regarding the actual use in the classroom we could not observe any indications of such being present since the teachers operated the devices in place. The second objective received $3 / 4$ since the students of Eklunda and Hanna had access to more than one device in their classrooms when they were engaged in educational activities. The third objective scored $2 / 3$. Here we had examined if they used more than one ICT device and could choose appropriate devices to complete their tasks. In the fourth objective, students appeared to be able to access, understand and manipulate digital information in such a way that it provided them with better education; thus, this objective scored 3/5. In all of the participant groups, the students interacted smoothly with their devices except for Brukets first graders, where the devices were mainly operated by the teacher. For this reason, objective five scored $4 / 5$.

\subsubsection{Collaboration and leadership}

Collaboration and leadership scored a total of 22/27 (81.5\%) (Table 10).The students acted in ways which shows they were fully capable of conducting collaboration between themselves. However signs of leadership were not really apparent. In the given tasks there were some students which had shown to be more knowledgeable and could provide guidance, motivation and influence the other classmates to their academic performances. By collaboration we want to state that the students were able to work together as a group efficiently in order to complete their given tasks. Some examples of collaboration that we had observed were that the students, when given an exercise/ task, able to work with each other. The students could decide together which would be the best course of action in order to complete their given tasks. During this collaboration one could find the following aspects: gestural and oral communication (pointing at screen, gestures, visualization, etc.), dividing the task between them, assigning roles, taking turns and crediting their partner for providing good ideas or good work (appreciation and acknowledgment).

We decided to view leadership as a role where one gets others to follow, looks up to and dictates common goals for more than at least one other person. This was not found in any of the participant groups; thus the score of $0 / 5$. The second objective scored $5 / 5$. Here we had mainly examined how they collaborated in their groups in accordance with the issues listed in Table 10. In the third 
objective, we had focused on their group behavior towards their fellow group members and it scored $5 / 5$. The fourth objective was found present in all participant groups since teamwork was a major element in how the educational activities took place. This thus scored $5 / 5$. For the fifth objective, we had examined communication among them which was of motivational, influential and mentoring type in team situations. For example the students would cheer (motivate) at their team member's ideas, stimulating their desire to stay committed to the task. They would also aid fellow team members with input such as advice or criticism (mentor), actions were also discussed during their team situations (influence). Hence they received a score of $4 / 4$. Finally, for the sixth objective, we observed that students were flexible and able to work with other people in varying situations and therefore it scored $3 / 3$.

\section{Conclusion}

This paper presents our investigations on how students at elementary schools interact through ICTs during their class room learning environment and how ICTs contribute toward their competencies building processes. We found that students became more concentrated, calm, structured, engaged and amused when operating ICT devices, thus learning became more interesting. There were found more engaged when working with computing devices than the traditional ways of learning. For example, documents are today written in an iterative manner, as ICT provides the opportunity of changes to be made. This is quite an improvement in productivity compared to the traditional method of first conceiving the entire document within the head and then painstakingly writing it down with a pencil, knowing that each failure to remember will lead to an ugly document by squeezing in small changes between the nicely written lines. Larger changes were not possible at all to make without rewriting the entire page on a new paper. But changing national tests may take a long time. If it is at all initiated; national school authorities today seem to tend to wait for the international tests such as PISA to make such changes because these tests are the yardstick they feel they need to fulfill the political goals of measurable progress in education. This way many issues are apparently being kept in limbo.

From the most frequent to the least common activities we found were: Educational application assignments (e.g. mathematics, geographic and vocabulary and geometry), Storytelling, Report Writing and Practical interaction assignments. We also found that most of the selected competencies from the AEFSL were present and contributed to the students' competencies building process when using ICTs in classrooms. Varying in strengths, the strongest to the weakest in regard to the competency building are: (1) collaboration and leadership, (2) communication, (3) digital and technological fluency, (4) creativity and innovation and (5) critical thinking, problem-solving and decision-making. In schools, integration of computing devices as part of improved teaching methods include comprehensive change in the view of education; for example, concerning the relation between teaching and learning, tests, teachers' work methods and role, and students' view of school work (Rosso, 2010). Local experiences are often stated as positive, which, on the one hand points to the importance of making a coherent, focused and ambitious effort at each school. On the other hand it is also an indication that there may be project effects, something that has been noted in the analysis by Hattie (2009); almost any intervention can lead to better results locally if much efforts and skills are put into it. Just like in any industry, effective production in school relies on quality-tested methods. Just like in any industry these will not happen spontaneously in all schools. Left alone, ICT use in schools will lead to increased differences among schools. While some will improve many will deteriorate.

This study is expected to shed light on how ICT takes place in classrooms, how it is used and which competency it aids to produce. Hopefully, these results contribute to the existing debate on whether or not the ICT devices helpful for students in achieving the learning goals. Given the small sample size ( 3 out of 59 municipality schools), future researchers may work on with the same objectives but with an increased sample. In complement, they may be interested in the following relevant research 
issues: (1) parents' roles: How parents are influenced by ICT devices while their children use them in schools? How many of them monitor their children's performance from home and how parents subsequently influence their children to perform better? Furthermore, how students behave when they know their parents are monitoring them and how do they feel? (2) Teachers' roles: What needs to be done in order for older teachers to be more capable of using ICTs these days for better educational outcomes? (3) Reward systems: How the reward-systems work to motivate children to perform better in their education and social environment? What is the most effective way of doing so?

\section{Notes}

1. List of schools in the municipality of Örebro: http://www.orebro.se/988.html

2. $P=$ Pre-school, below seven-year-old children. First graders usually start at the age of seven in Sweden.

3. Assistants such as employed teachers with lower hierarchical rank in the classroom than an ordinary teacher.

\section{Disclosure statement}

No potential conflict of interest was reported by the authors.

\section{Notes on contributors}

Johannes S. Sahlin is a postgraduate student in Information Systems (IS) at the Informatics unit of Örebro University School of Business, Sweden. Johannes is specialized in software development and IT Project Management. Johannes had been involved in various software development projects as a project manager and software developer in Sweden. He has recently received MSc in IS with specialization in IT in Public Administration (eGovernment) and and IT Project Management. He took his BSc in the same field in 2013 from Örebro University, Sweden.

Antony Tsertsidis is a postgraduate student specialized in IS at the Informatics unit of Örebro University School of Business, specialized in IT in Project Management and IT in Public Administration. During his previous years, Antony has been working as a full-time technical documents translator (English-Greek and vice versa) and as an IT support technician. Antony recently received his MSc in IS with specialization in IT in Public Administration (eGovernment) from the University of Örebro and in 2012 received his BSc in Computing from the University of East London.

Dr M. Sirajul Islam (Siraj) is an assistant professor in IS at the Informatics unit of Örebro University School of Business, Sweden. Siraj is specialized in teaching and research in the areas of eGovernment, ICTs for development (ICT4D) with special interest in marginalized communities in developing regions, and ICTs for Education. He is currently teaching both at the graduate and postgradute levels. He has also been involved with some journal editorial/review committees and international conferences relevant to ICT4D and eGovernment researches.

\section{References}

Ackermann, E. (1996). Perspective-taking and object construction. In Y. Kafai \& M. Resnick (Eds.), Constuctionism in practice: Designing, thinking, and learning in a digital world (pp. 25-37). Mahwah, NJ: Lawrence Erlbaum Associates. Retrieved from http://web.media.mit.edu/ edith/publications/1996-persp.taking.pdf

Alberta. (2011). Alberta Education Framework for student learning: competencies for engaged thinkers and ethical citizens with an entrepreneurial spirit. Retrieved April 7, 2015, from http://education.alberta.ca/department/ipr/curriculum.aspx

Ardito, G. (2011). The shape of disruption: Student independence in the 5th grade classroom. In T. Bastiaens \& M. Ebner (Eds.), Proceedings of world conference on educational multimedia, hypermedia and telecommunications 2011 (pp. 2129 2133). Chesapeake, VA: AACE. Austin, TX: Texas Center for Educational Research.

Bebell, D. (2005). Technology promoting student excellence: An investigation of the first year of 1:1 computing in New Hampshire middle schools. Paper presented at the annual meeting of the national educational computing conference, Philadelphia.

Bebell, D., \& Kay, R. (2010). One to one computing: A summary of the quantitative results from the Berkshire wireless learning initiative. Journal of Technology, Learning, and Assessment, 9(2), 1-60. Retrieved from https://ejournals.bc. edu/ojs/index.php/jtla/article/viewFile/1607/1462

Bebell, D., \& O'Dwyer, L. M. (2010). Educational outcomes and research from 1:1 computing settings. Journal of Technology, Learning, and Assessment, 9(1). Retrieved May 25, 2015, from http://www.jtla.org 
Bonifaz, A., \& Zucker, A. (2004). Lessons learned about providing laptops for all students. Northeast and the Islands Regional Technology in Education Consortium (NEIRTEC), Education Development Center, Inc. (EDC). Retrieved from www.neirtec. org/laptop/LaptopLessonsRprt.pdf

Brown, J. S., Collins, A., \& Duguid, P. (1989). Situated cognition and the culture if learning. Educational Researcher, 18(1), 32-42.

Clarfield, J., \& Stoner, G. (2005). The effects of computerized reading instruction on the academic performance of students identified with ADHD. School Psychology Review, 34(2), 246-254.

Constant, M. D. (2011). One-to-One laptop project: Perceptions of teachers, parents, and students (Dissertation). Western Kentucky University, USA, 5.

Cristia, J. P., Ibarrarán, P., Cueto, S., Santiago, A., \& Severín, E. (2012). Technology and child development: Evidence from the one laptop per child program. Inter-American Development Bank. Retrieved from http://idbdocs.iadb.org/wsdocs/ getdocument.aspx?docnum $=36706954$

Driver, M. (2002). Exploring student perceptions of group interactions and class satisfaction in the web-enhanced classroom. The Internet and Higher Education, 5, 35-45.

Engeström, Y. (1987). Learning by expanding: An activity-theoretical approach to developmental research. Helsinki: OrientaKonsultit.

Fairman, J. (2004). Trading roles: Teachers and students learn with technology. Orono, ME: Maine Education Policy Research Institute, University of Maine Office. Retrieved from http://usm.maine.edu/sites/default/files/Center\%20for\% 20Education\%20Policy,\%20Applied\%20Research,\%20and\%20Evaluation/MLTI_Report3.pdf

Grasso, I., \& Fallshaw, M. (Eds.). (1993). Reflections of a learning community: Views on the introduction of laptops at MIC by Methodist Ladies' college. Melbourne: Methodist Ladies' College. Retrieved from http://stager.tv/blog/?tag=seymourpapert

Great Maine Schools Project. (2004). One-to-one laptops in a high school environment: Piscataquis Community High School study. Final Report, Senator George J. Mitchell Scholarship Research Institute, USA.

Gulek, J., \& Demirtas, H. (2005). Learning with technology: The impact of laptop use on student achievement. Journal of Technology, Learning, and Assessment, 3(2), 3-6.

Hashim, N., \& Jones, M. L. (2007, 3-5 September). Activity theory: A framework for qualitative analysis. Paper presented at international qualitative research convention (QRC), PJ Hilton, Malaysia.

Hattie, J. (2009). Visible learning: Visible learning: A synthesis of over 800 meta-analyses relating to achievement. London: Routledge.

Hsu, S. (2011). Who assigns the most ICT activities? Examining the relationship between teacher and student usage. Computers \& Education, 56(3), 847-855. Retrieved from http://www.sciencedirect.com.db.ub.oru.se/science/article/ pii/S0360131510003180

Ingram, D., Willcutt, J., \& Jordan, K. (2008). Laptop initiative: Evaluation report. Center for applied research and educational improvement, University of Minnesota, USA. Retrieved from http://oakland2.stillwater.k12.mn.us/sites/f1c1a073-106e4552-82a3-3b75eff284c3/uploads/CAREI_Report.pdf

Islam, M. S., \& Andersson, A. (2016). Investigating choices of appropriate devices for one-to-one computing initiatives in schools worldwide. International Journal of Information and Education Technology, 6(10), 817-825. Retrieved from http://www.ijiet.org/show-78-904-1.html

Islam, M. S., \& Grönlund, Å. (2016). An international literature review of 1:1 computing in schools. Journal of Educational Change. doi:10.1007/s10833-016-9271-y

Karanasios, S. (2014). Framing ICT4D research using activity theory: A match between the ICT4D field and theory? [IFIP Special Issue]. Information Technologies \& International Development, 10(2), 1-19.

Kay, A. C. (1972). A personal computer for children of all ages. Xerox Palo Alto Research Center. Retrieved from http://www. mprove.de/diplom/gui/Kay72a.pdf

Keengwe, J., Schnellert, G., \& Mills, C. (2012). Laptop initiative: Impact on instructional technology integration and student learning. Education and Information Technologies, 17, 137-146.

Laptop.org (web). Retrieved from http://one.laptop.org/

Lindström, K. (2015, April 20). Computer Sweden. Retrieved April 25, 2015, from Computer Sweden. Retrieved from http:// computersweden.idg.se/2.2683/1.621787/nu-ar-det-bevisat-barnen-blir-battre-i-skolan-med-surfplattor

Livingstone, S. (2012). Critical reflections on the benefits of ICT in education. Oxford Review of Education, 38, (1), 9-24. Retrieved from http://www.tandfonline.com/doi/abs/10.1080/03054985.2011.577938

Lowther, D. L., Strahl, J. D., Inan, F. A., \& Bates, J. (2007). Freedom to learn program. Michigan 2005-2006 evaluation report. Center for Research in Educational Policy, The University of Memphis. Retrieved from http://www.memphis.edu/crep/ pdfs/Michighan_Freedom_to_Learn_Laptop_Program.pdf

MacArthur, C. A., Haynes, J. A., \& Malouf, D. B. (1986). Learning disabled students' engaged time and classroom interaction: The impact of computer assisted instruction. Journal of Educational Computing Research, 2(2), 189-198.

Mautone, J. A., DuPaul, G. J., \& Jitendra, A. K. (2005). The effects of computer-assisted instruction on the mathematics performance and classroom behavior of children with ADHD. Journal of Attention Disorders, 9(1), 301-312.

Negroponte, N. (2006). Nicholas Negroponte on one laptop per child. Retrieved from http://www.ted.com/talks/nicholas negroponte_on_one_laptop_per_child.html 
Nonaka, I., \& Toyama, R. (2003). The knowledge-creating theory revisited: Knowledge creation as a synthesizing process. Palgrave Journal - Knowledge Management Research \& Practice, 1, 1-9.

Norris, C., \&Soloway, E. (2010, May). One-to-one computing has failed our expectations. District Administration. Retrieved May 25, 2015, from http://www.districtadministration.com/article/one-one-computing-has-failed-our-expectations

Oates, B. J. (2006). Researching information systems and computing. London: SAGE Publications.

Oliver, K. M., \& Corn, J. O. (2008). Student-reported differences in technology use and skills after the implementation of one-to-one computing. Educational Media International, 45(3), 215-229.

Ota, K. R., \& DuPaul, G. J. (2002). Task engagement and mathematics performance in children with attention-deficit hyperactivity disorder: Effects of supplemental computer instruction. School Psychology Quarterly, 17(3), 242-257.

Papert, S. (1986). Constructionism: A new opportunity for elementary science education. Massachusetts Institute of Technology, Media Laboratory, Epistemology and Learning Group. Retrieved from http://nsf.gov/awardsearch/ showAward.do?AwardNumber $=8751190$

Pärsson, E. (2015, June 9). Alliansens förslag: Så ska vi digitalisera skolan. Retrieved June 20, 2015, from http://www.svd.se/ alliansen-vill-se-snabbt-it-lyft-for-barn

Ragan, E. D., Jennings, S. R., Massey, J. D., \& Doolittle, P. E. (2014). Unregulated use of laptops over time in large lecture classes. Computers \& Education, 78, 78-86.

Rockman, S. (2004). Getting results with laptops. Technology \& Learning, 25(3), 1-12. Retrieved from http://www. techlearning.com/news/0002/getting-results-with-laptops/59638

Rockman, S., Walker, L., \& Chessler, M. (2000). A more complex picture: Laptop use and impact in the context of changing home and school access. The third in a series of research studies on Microsoft's Anytime Anywhere Learning Program. San Francisco, CA: Rockman, et al. Retrieved from http://www.rockman.com/projects/126.micro.aal/yr3_report.pdf

Rosso, J. (2010). Disruption in the educational paradigm: Notes on 1:1 research. Research watch, K-12 Blueprint. Retrieved from http://www.k12blueprint.com/content/disruption-educational-paradigm-notes-11-research

Roush, W. (2014, March 20). One Laptop Per Child CEO Responds to Flap: 'We Have Achieved Our Goals'. xconomy.com. Retrieved from http://www.xconomy.com/boston/2014/03/20/one-laptop-per-child-ceo-we-have-achieved-our-goals/

Scanlon, E., \& Issroff, K. (2005). Activity theory and higher education: Evaluating learning technologies. Journal of Computer Assisted Learning, 21, 430-439.

Toyama, K. (2011). There are no technology shortcuts to good education. Retrieved from http://edutechdebate.org/ict-inschools/there-are-no-technology-shortcuts-to-good-education/\#sthash.Kisxbb1P.dpuf. Retrieved June 13, 2015, from http://edutechdebate.org/ict-in-schools/there-are-no-technology-shortcuts-to-good-education/

Trimmel, M., \& Bachmann, J. (2004). Cognitive, social, motivational and health aspects of students in laptop classrooms. Journal of Computer Assisted Learning, 20, 151-158.

Van Son, R. (2011). The question is not whether, but how ICT can be useful in education. Retrieved June 30, 2015, from http:// edutechdebate.org/ict-in-schools/the-question-is-not-whether-but-how-ict-can-be-useful-in-education/

Warschauer, M., \& Ames, M. (2010). Can one laptop per child save the world's poor? Journal of International Affairs, Fall/ Winter, 64(1). Retrieved from http://jia.sipa.columbia.edu/files/jia/033-051_Warschauer_bluelines.pdf

Wilson, V. (2014). Examining teacher education through cultural historical activity theory. Tean Journal, 6(1), 20-29.

Zuckerman, E. (2007). One laptop per child: Just what sort of content do you load onto these puppies? Retrieved from http:// www.ethanzuckerman.com/blog/2007/01/22/one-laptop-per-child-just-what-sort-of-content-do-you-load-ontothese-puppies/

Zucker, A. A., \& McGhee, R. (2005). A study of one-to-one computer use in mathematics and science instruction at the secondary level in Henrico County Public Schools. Arlington, VA: SRI International. 